\title{
Journal of Arts and Social Sciences
}

\author{
https://ojs.jass.pk
}

Investigating Several Similar Questions Types in Turkish, Kurdish, English, Russian and

German

\author{
Dr. Mehmet Veysi BABAYİĞİT*
}

* School of Foreign Languages, Turkey Batman University

\begin{tabular}{|c|c|}
\hline A R T I CLE I N F O & A B S T RA C T \\
\hline $\begin{array}{ll}\text { Article history: } \\
\text { Submitted } & 13.08 .2021 \\
\text { Accepted } & 24.11 .2021 \\
\text { Published } & 30.12 .2021 \\
\end{array}$ & $\begin{array}{l}\text { Language is used as a tool of communication in all over the world, and } \\
\text { each society or country may adopt a different language leading various dialects } \\
\text { or language usages. In order to interrogate different aspects, multiple question }\end{array}$ \\
\hline $\begin{array}{l}\text { Volume No.8 } \\
\text { Issue No.II } \\
\text { ISSN (Online) 2414-8512 } \\
\text { ISSN (Print) 2311-293X } \\
\text { DOI: }\end{array}$ & $\begin{array}{l}\text { information about a topic / issue, ask for confirmation, request something or } \\
\text { clarify some controversial aspects almost in all languages.In addition, some } \\
\text { questions are directed to speakers via question words such as what, where or } \\
\text { how; on the other hand, some questions are conducted via helping verbs, } \\
\text { adjuncts or question tags. Foreign language learners first learn affirmative, }\end{array}$ \\
\hline $\begin{array}{l}\text { Keywords:Question, } \\
\text { Types,Similarities, } \\
\text { Kurdish, English, Turkish, } \\
\text { German, Russian }\end{array}$ & $\begin{array}{l}\text { then negative and finally questions forms in the target language that is why it } \\
\text { may be inferred that using questions in a language requires improvement and } \\
\text { experience.The current study aims to find out some similar questions types in } \\
\text { Turkish, English, Kurdish, Russian and German; hence, an analysis has been } \\
\text { conducted on question samplesobtained descriptively in those languages.The } \\
\text { results of the analysis indicated that there are some similar types of questions } \\
\text { such as general questions, special questions, tag questions and alternative } \\
\text { questions in those languages. } \\
\text { (c) }) \text { (i) }\end{array}$ \\
\hline
\end{tabular}

\section{Introduction}

Language has the strength to overview many ideas and issues in the world as learners can shape their identity and can get information about the world.Language also posits a significant role in terms of conveying and receiving communicative messages among human beings. While seeking information, different forms of structures are employed. Also, while investigating language forms, we shouldn't focus on just a technic or method (Babayiğit, 2020a), and this indicates that a wide range of forms which aregenerally considered as questions should be included.

The current study has employed five languages which are Turkish, English, Kurdish, Russian and German; Turkish language holds a history of 9000 years and there are many periods for the development of that language (Şanlı \& Jable, 2009). It is believed that the linguistic changes and shifts in Turkish language are the results of occurrence of various political, sociologic, economic and cultural aspects throughout the history (Bahattin, 2003). Regarding Kurdish language, it is claimed that it is spoken in different parts of Turkey such as the cities in the south-east region (Bulak, 2020), and it is believed that it belongs to the Northwest Iranian branch of the Indo-Iranian languages within the Indo-European language family (Blau, 1992). Although English language is commonly employed in many parts of the world for different purposes such as economy, 
transportation, education, tourism, business, etc., this language is not as old as Turkish and Kurdish. It is believed that English has become officially used by Britian after $14^{\text {th }}$ A.D. for educational and politic purposes at first (Tutaş, 2017), and then it has gained popularity in many domains. Hence, many words from German and French were borrowed due to political bonds and wars among those societies (McCormic, 1979:75; Priestley \& Spear, 1963:102). Also, English, French and German are considered to be in the same language family since these similar words are widespread in those languages, and although there may be some minor differences in terms of pronunciation and spelling, they almost reflect the same meaning.

Considering Russian Language, it is claimed that it is one of the most spoken language in the world, and although the exact time of the Russian language is not known, it is believed that Russian occurred as a result of Slavic languages in 850s and employs CyrillicAlphabet which is rather different from Latin alphabet. Besides, relations in terms of war, trade, politic and economy accelerated the dissemination of that language in the history (Karpova, 2019). Furthermore, German is considered to be the Germanic branch of the Indo-European languages, and one of the common languages in the world, thus, it may be claimed that itis one of the official languages of the European Union and the most widely spoken. Likewise, German has also undergone different periods of change in linguistics issues; thus, it is possible to monitor different variants related to language in the language history of German (Gloning\& Young, 2004).Thus, it may be asserted that all of the languages experience distinctive periods while gaining linguistic changes and updates.

\section{Objectives of the study}

The rationale for conducting the current study is to illustrate the similar question types in various languages. In other words, though there is a vast number of languages on the earth, the functional issue of the language which is "communication" do not differ; hence, the universal functions of questions in multiple languages are aimed to be indicated via comparing multiple question types in those languages. Since this study is a comparative linguistics study, it is believed that it successfully highlights the linguistics circumstances and features of multiple languages in a comparative manner (Babayiğit, 2020c). Thus, the following objectives are targeted;

- To investigate and compare similar question types in Turkish, English, Kurdish, Russian and German.

- To illustrate the number of the question types, and to compare the similarities among them.

- To propose the universal functions of various question types in those languages.

- To highlight the communicative roles of questions in initiating, keeping and ending turns in talks.

- To define various question words and their syntactical usages in those languages.

In sum, even though each language is incorporated with many distinctive features in terms of productive and received skills based on grammar, speech, writing etc., the issue of language forms are universal. Hence, investigating the functional aspects of question types may not be concealed in order to come up with affluent communicative functions and demolish language barriers in a certain target language.

\section{Literature Review}

While speaking a language regardless of being a native or target language, it is always entailed to hold efficient communicative skills; thus, many interactants and communicators employ comprehensible speeches such as various questions to make the conversational aspects or on-going processes fluent.

Regarding the core role of the questions in the communicational issues, it may be claimed that questions not only teach us but also make us learn new views and gain knowledge about a specific domain since they carry different roles in a society (Levinson, 1979). Investigating questions types and including them in classroom practices may yield fruitful data because students are able to L1 and L2's successful adjustment and produce corrections of errors by incorporating 
drills and practises (Pica, 1994). Besides, questions have roles in many task-based exercises in the class that is why students can grasp the crucial points by paying attention to the question-answer practices in a manner of communicative language practice (Littlewood, 2004). While asking questions in the classroom, it is also crucial to care the context in order to get effective communication skills (Babayiğit, 2020b). It is believed that effective communication makes expressions more meaningful both in written and spoken language.

In addition, questions are one of the most common used instructional strategies almost in all departments by teachers (Graesser, Rus, Cai \& Hu, 2012). These questions can be present in the texts or tasks apart from oral speeches in the classrooms (Rittle-Johnson, 2006). Generally, natural question are generated in order to seek language processing techniques and come up with question generations forms either syntactic or semantic in the classroom contexts(Lindberg, D., Popowich, F., Nesbit, J., \& Winne, P. , 2013) ; however, it is clear that syntax-based methods are generally adopted while constituting a question or using questions words in many languages (Kalady et al. , 2012). That is why using questions in communication is crucial and there are some certain points why we do use questions.

Why do we use questions in our communication?

There are many purposes of asking questions and the following items illustrate these purposes;

1- To get information or knowledge about something

2- To demolish confusion about something

3- To direct a conversation.

4- To being and empower a relationship

5- To find a solution for a problem.

6- To enable interaction among speakers in order to evoke creativity in defining various ideas.

7- To change or affect someone's ideas or knowledge about a specific issue.

8- To come up with an agreement or disagreement about a topic or fact.

The roles of questions is really encouraging in language teaching curriculum, and it is believed that learners may able to boost their foreign language speaking skills and raise their awareness by initiating discussions via questions in foreign language teaching programs (Lync, 1991). Shomoossi (2004) claims that employing questions in language teaching classroom contexts help learners gain awareness about the topic and conversation, thus they let them activate their minds and experience topics in real contexts. It is also asserted that conducting many types of questions in classroom contexts are efficient in triggering learners' critical skills and letting them develop communicative language use (Lee, 2006). Carlson \& Tanenhaus (1988) claimed that questions play a central role in learning a foreign language because they facilitate understanding the thematic roles and impeding barriers in the target language. Thus, it is clear that employing questions in teaching and learning the target language is rather crucial because it helps grasping thematic and conceptual issues in the target language easily thanks to the communicative roles of the questions in the conversations.

In conclusion, it may be asserted that questions are available in all languages, and they bear distinctive features for a certain language because they facilitate language learning, language teaching, discussion, comprehension and communication among human beings.

\section{METHODOLOGY}

While conducting the current study, goals and procedures have been taken into consideration to report data about daily conversational dialogues. Thus, the main purpose of the current study is to investigate various question types such as general questions, special questions, tag questions and alternative questions in multiple languages based on both formal and informal dialogues; hence, the current study has employed Turkish, Kurdish, English, Russian and German. While conducting the current study, the following research questions were taken into consideration;

1- What are the similarities among question types in Turkish, Kurdish, English, Russian and German? 
2- What are the functions of question types in Turkish, Kurdish, English, Russian and German?

Besides, before collecting data and analysing the data for the current study, some basic hypotheses were designed in order to define the pre-suppositions about the expected results. Following hypotheses highlight some views about the current study;

H1: There are similar question types in Turkish, Kurdish, English, Russian and German.

H2: Functions of some certain question types in Turkish, Kurdish, English, Russian and German hold no specific discrimination.

Since the current study is a descriptive study, there are no specific participants, and the whole data have been obtained from both formal and informal daily conversations. Also, a wide range of data scope is not included because the core and basic concepts on forming question types in those languages and similarities among these questions types are aimed. While analysing the question types, content analysis was used in order to reveal the distinctive and core similarities among those question types in mentioned languages. Besides, similar question words, exclamations, and expressions are analysed equally, and these similarities are aimed to be shown in the tables.

\section{FINDINGS}

\subsection{Question Types}

\subsubsection{General questions inTurkish, Kurdish, English, Russian and German}

These are common questions which can be answered by yes/no; hence, these are also named as yes/no questions.General questions are widespread in both languages. While asking these questions, there is no adjunct in both languages.

Some Samples in Turkish,English, Kurdish, Russian and German for General Questions

\begin{tabular}{|l|l|l|}
\hline A: Bu gece eve geliyor musun? & $\begin{array}{l}\text { A: Are you coming home tonight? } \\
\text { B: Evet. }\end{array}$ & $\begin{array}{l}\text { A: Issev, tu tê malê? } \\
\text { B: Erê. }\end{array}$ \\
C: Kitabinizı alabilir miyim? & C: Can I take your book? & C: Ez karim pirtûka te bigrim? \\
D: Hayır. & D: No. & Da. \\
E: Ah, yemek yiyecek misin? & E: Ah, will you have dinner? & E: Ma, hûn êxwarinê bixwin? \\
F: Evet. & F: Yes. & F: Erê. \\
& & \\
\hline
\end{tabular}

\begin{tabular}{|l|l|}
\hline A: Ты идешь домой сегодня вечером? & A: Kommst du heute Abend nach Hause? \\
В: Да. & B: Ja. \\
& \\
C: Могу я взять вашу книгу? & C: Darf ich Ihr Buch mitnehmen? \\
D: Нет. & D: Nein. \\
& E: Ah, wirst du zu Abend essen? \\
E: A, вы поужинаете? & F: Ja. \\
\hline
\end{tabular}

Considering the whole tables in those five languages, it may be asserted that while asking general questions, there is a need for helping verb such as "can", "am", "is", "are" etc. in English, "mi", "mı", "mu", "mü" etc in Turkish, suffixes at the end of the words in Russian and German; however, there are no clear helping words or suffixes in Kurdish in order to form general questions in various target languages.

\subsubsection{Special questions in Turkish, Kurdish, English, Russian and German}

Special questions are used to get specific information about something or someone.These are also named as wh-questions in English.The questions words are who, what, where, when, why, how, how many, etc. It is likelihood to come up with these question words in Turkish, Kurdish, Russian and German.

Samples in Turkish, Kurdish, English, Russian and Germanfor Special Questions

\begin{tabular}{|l|l|l|}
\hline A: Nerelisin? & A: Where are you from? & A: Tu ji ku/ kuderê ŷ̀े? \\
B: Diyarbakir. & B: Diyarbaktr. & B: Amed. \\
C: Kitabin adı ne? & C: What is the name of the book? & C: Navê vê pirtûkê çi ye? \\
D: Emily & D: Emily & D: Emily \\
E: Bugün hava nasill? & E: How is the weather today? & E: Hewa îro çawa ye? \\
F: Güneşli. & F: Sunny. & D: Bi tav e. \\
\hline
\end{tabular}




\begin{tabular}{|c|c|c|}
\hline $\begin{array}{l}\text { G: Baban kim? } \\
\text { H: Muhammed }\end{array}$ & $\begin{array}{l}\text { G: Who is your father? } \\
\text { H: Muhammed }\end{array}$ & $\begin{array}{l}\text { E: Bavê te kî ye? } \\
F: \text { Muhammed. }\end{array}$ \\
\hline
\end{tabular}

\begin{tabular}{|l|l|}
\hline A: Ть откуда? & A: Woher kommst du? \\
В: Диярбакыр. & B: Diyarbakır. \\
С: Как называется книга? & C: Wie heißt das Buch? \\
D: Эмили & D: Emily \\
Э: Какая сегодня погода? & E: Wie ist das Wetter heute? \\
F: Солнечно. & F: Sonnig. \\
G: Кто твой отеи? & G: Wer ist dein Vater? \\
Н: Мухаммед & H: Muhammed \\
& \\
\hline
\end{tabular}

The samples about special question types in Turkish, Kurdish, English, Russian and German indicate that there are various question words in each mentioned language to conduct questions. In other words, "what, where, how, why, who" etc. are used for English; "ne, nerede, nasıl, neden, kim" etc. are used for Turkish;"çi, li ku / kuderê, çawa, çima, kî" etc. are used for Kurdish; "was, wo, wie, warum, wer" are used for German, and "Что, где, как, почему, кто" are used for Russian.

\subsubsection{Tag questions in Turkish, Kurdish, English, Russian and German}

This type is also named as disjunctive questions.In English, the questions are made up of two parts, where the first part is a positive statement, and the second part is negative, or vice-versa.In Kurdish, there are two parts the same as in English; however, the second part is generally negative. These show similar aspects for the other languages which are Turkish, Russian and German.

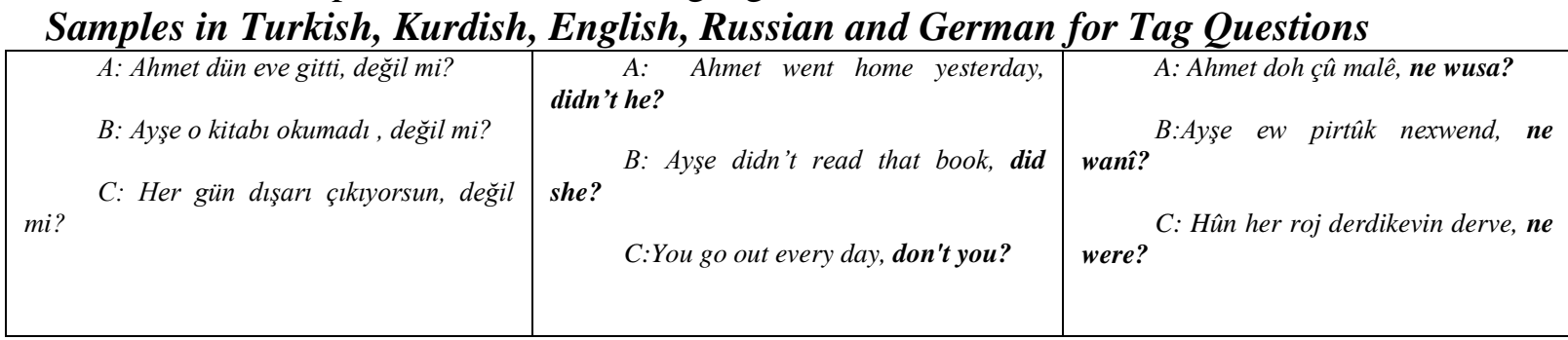

\begin{tabular}{|c|c|}
\hline $\begin{array}{l}\text { A: Ахмет вчера уехал домой, } \\
\text { не так ли? }\end{array}$ & $\begin{array}{l}\text { A: Ahmet ist gestern nach Hause } \\
\text { gegangen, nicht wahr? }\end{array}$ \\
\hline $\begin{array}{l}\text { В: Айме не читала эту книгу, } \\
\text { не такли? } \\
\text { С: Вы выходите из дома } \\
\text { каждый день, не такли? }\end{array}$ & $\begin{array}{l}\text { B: Ayşe hat das Buch nicht gelesen, } \\
\text { oder? } \\
\text { C: Du gehst jeden Tag aus, nicht } \\
\text { wahr? }\end{array}$ \\
\hline
\end{tabular}

The samples of Tag questions in Turkish, Kurdish, English, Russian and German reveal that there are various indicators in order to get confirmation from the speaker of the target language. To exemplify, "değil mi?" is commonly used for Turkish; negative and affirmative helping verbs such as “do, does, don't, doesn't, did, didn't, has, have, hasn't, haven't, can, can't, could, couldn't" etc. based on the forms of the sentences are used in English; expressions such as"ne wanî?, ne wusa?, ne were?" are employed in Kurdish; “не так ли?" is used for Russian, and finally "nicht wahr?" and "oder?" are used for Germany. Considering all of these expressions in those languages, it may be claimed that they all hold the function of being tag questions in order to get confirmation in a conversation.

\subsubsection{Alternative questions in Turkish, Kurdish, English, Russian and German}

This type is also named as choice questions.At least two options are offered to the speakers in the conversations. These questions can be either general or specific ones. 


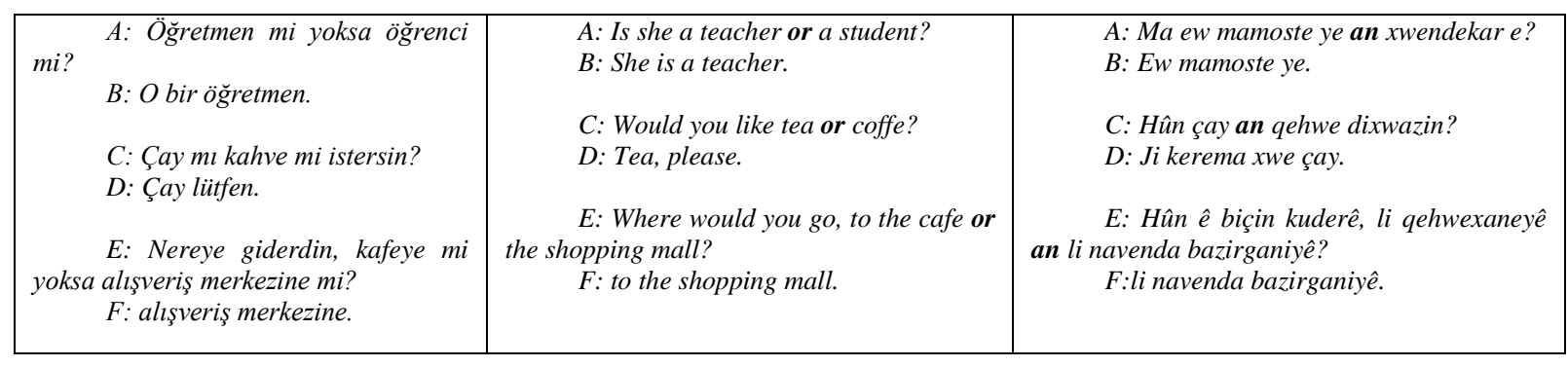

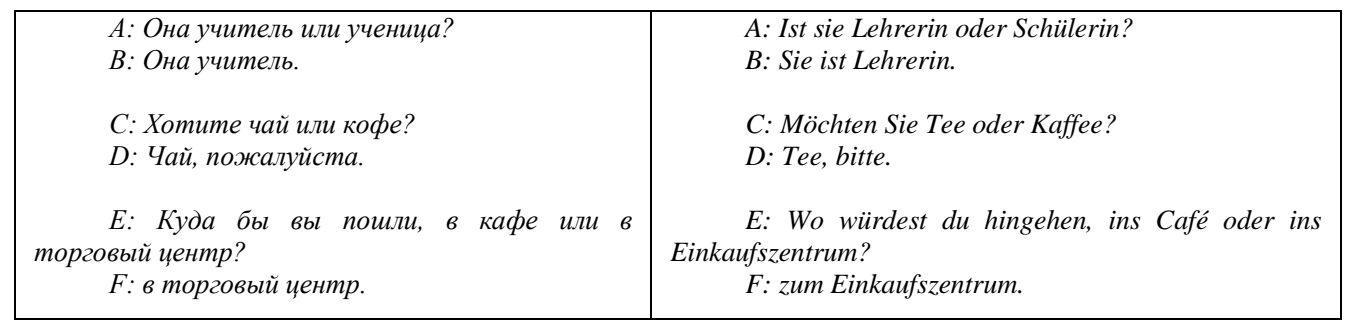

Samples from the he tables about alternative questions in Turkish, Kurdish, English, Russian and German show that all of the words hold the same function of question in the those languages; however, they differ in terms of spelling and position of the word in the sentences. The word used to show an alternative in those questions in the tables holds the function of illustrating another option, and this word is "m1..mi", "yoksa" , "ya... ya da" in Turkish; "or" in English; "an" in Kurdish; "или” in Russia, and "oder" in German.

\section{Conclusion}

The current study revealed that language is used to interrogate many various things and learn some specific aspects.People may also shape their identity or knowledge via asking multiple questions. There are various questions asked almost in all languages since this is a basic requirement for a successful communication among human beings. The results of the current study claimed that there are various question types such as general questions, special questions, tag questions and alternative questions in Turkish, Kurdish, English, Russian and German.Although the words and syntax differ in the sentences, they all bear the same functions and meanings in all of those languages employed in the current study. Hence, it is possible to claim that holding distinctivelanguage family groups or to be spoken in multiple parts of the worlds may hold no effect on the function of the questions because the core and implied meaning in a sentence may be indicated in similar ways thanks to various employed questions types. It is also possible to obtain similar functions or types of questions in many different languages spoken in different parts of the world since questions hold a crucial role in initiating, continuing and finalizing conversations among human beings.

\section{Implications And Discussion}

The present study aims to find out various question types such as general questions, special questions, tag questions and alternative questions in multiple languages such Turkish, Kurdish, English, Russian and German based on both formal and informal dialogues. The data were obtained various daily conversations including similar dialogues in those languages, and the whole obtained data were analysed in terms of content to reveal distinctive question types and their functions in terms of similarity. The results revealed that there are similarities in terms of question types and functions; hence, the obtained results are compatible with the defined hypotheses. Also, it may be claimed that the research questions are efficient in terms of conducting the study affluently. Besides, the current study has employed unique samples from both eastern and western languages in a distinctive manner.

However, it may be more subtle to conduct the current study with more languages by incorporating various linguistics aspects or language forms. Since the number of current studies on 
comparative linguistic researches is rather rare, it may be more influential to conduct similar studies employing many distinctive languages from different language families. Besides, conducting an experimental study on observing and assessing perceptions of multiple participants about various question types and their functions in different languages may reveal more valid and reliable results for further studies.

\section{References}

Babayiğit, M. V. (2020a). What Do English Teachers Keep in Their Notes for the Students? The profits of Field Notes for the Development of Language Skills. 2nd ECLSS International Online Conference on Economics and Social Sciences, 468-471, June 28-29, Istanbul, Turkey.

Babayiğit, M. V. (2020b). Does Multimedia Technology Facilitate Pragmatics Awareness among Teenage Learners? A Case of Secondary-School Students. International Journal of Kurdish Studies, 6(2), 164-174.

Babayiğit, M. V. (2020c). Kürtçe, Türkçe ve İngilizce Atasözlerinde Azim, Başarı, Çalışkanlık, Kararl1lık ve Tembellik İfadeleri. International Journal of Kurdish Studies 6 (2), 244 - 257, DOI: https://doi.org/10.21600/ijoks. 760441.

Bahattin, S. A. V. (2003). Anlam Değişmeleri Üzerine Artzamanlı Bir İnceleme. Gazi Üniversitesi Gazi Eğitim Fakültesi Dergisi, 23(1).

Blau, J. (2003). The Kurdish Language and Literature. Paris: InstituteKurde. org.

Bulak, Ş. (2020). Dünya'da ve Türkiye'de Yaşayan Diller Üzerine. Journal of International Social Research, 13(71).

Carlson, G. N., \& Tanenhaus, M. K. (1988). Thematic roles and language comprehension. Syntax and semantics, 21, 263-288.

Gloning, T., \& Young, C. (2004). A history of the German language through texts. Routledge.

Graesser, A. C., Rus, V., Cai, Z., \& Hu, X. (2012). Question answering and generation.In Applied Natural Language Processing: Identification, Investigation and Resolution (pp. 1-16). IGI Global.

Kalady, S., Elikkottil, A., \& Das, R. (2010, June). Natural language question generation using syntax and keywords. In Proceedings of QG2010: The Third Workshop on Question Generation (Vol. 2, pp. 5-14). Questiongeneration. org.

Karpova, V. (2019). Türkçe-Rusça Eş Değer Atasözleri Üzerine Inceleme. (Doctoral dissertation). Marmara University, İstanbul, Turkey.

Lee, Y. A. (2006). Respecifying display questions: Interactional resources for language teaching. Tesol Quarterly, 40(4), 691-713.

Levinson, S. C. (1979). Activity types and language. Linguistics, 17, 365-399.

Lindberg, D., Popowich, F., Nesbit, J., \& Winne, P. (2013, August). Generating natural language questions to support learning on-line. In Proceedings of the 14th European Workshop on Natural Language Generation (pp. 105-114).

Littlewood, W. (2004). The task-based approach: Some questions and suggestions. ELT Journal, 58(4), 319-326.

Lynch, T.(1991). Questioning Roles in the classroom. ELT Journal 45 (3): $201-210$.

Mccormic, P. (1979). Adventures in English Literature (Classic Edition). New York: Hartcourt Brace \& World.

Pica, T. (1994). Questions from the language classroom: Research perspectives. Tesol Quarterly, 28(1), 49-79.

Priestly. J. B. \& Spear, J. (1963). Adventures in English Literature (Laurreate Edition). New York: Hartcourt Brace \& World. ,

Rittle-Johnson, B. (2006). Promoting transfer: Effects of self-explanation and direct instruction. Child development, 77(1), 1-15.

Shomoossi, N. (2004). The effect of teachersquestioning behavior on EFL Classroom interaction: A 
classroom research study. The Reading Matrix, 4(2).

Şanlı, C., \& Jable, E.(2009). Balkanlarda Türk Dili ve Edebiyatı.1.Uluslararası Balkanlarda Tarih ve Kültür Kongresi, Kosovo.

Tutaş, N. (2017). İngiliz Dilinde 'Aydınlanma': Eski İngilizce'den Günümüze Değişimi ve Gelişimi. Ankara Üniversitesi Dil ve Tarih-Coğrafya Fakültesi Dergisi, 54(1). 